\title{
Reframing Public Educational Services and Programs as Tradable Commodities - A Synthesis and Critique of British Columbia's Bill 34
}

\author{
Gérald Fallon \\ University of Western Ontario \\ Sonya Pancucci \\ Brock University
}

\begin{abstract}
This paper is a critical analysis of British Columbia's controversial Part 6.1 of the School Amendment Act 2002 (Bill 34) as it relates to the reframing of public educational services and programs as a tradable commodity. It enables public school districts to incorporate private companies to set up offshore schools and to market educational services and programs locally, nationally, and internationally. Policymakers introduced this Bill with the assumption that public educational institutions must compete with other "providers," to sell their services and programs effectively in order to keep revenues at a healthy level to ensure their institutional viability and relevancy. This paper examines the goals, motives, and assumptions behind Bill 34, and, more specifically, the extent to which Part 6.1 of Bill 34 incorporates a market approach to public education as it commodifies public educational services and programs and creates competitive arrangements between public educational institutions.
\end{abstract}

\section{Introduction}

This paper is an attempt to understand some of the multiple and complex effects of globalization on educational policy and policy formation. It stems from our personal concerns about the emergence of a market-oriented approach to educational issues as the dominant paradigm for constructing and implementing public education policy in British Columbia (BC). Despite policy-makers' claims about the need to prepare individuals for competition in the global economy (The Select Standing Committee Report on Education, 2002), we believe this approach subtly expresses a concealed ideological agenda in which

Gérald Fallon is a PhD candidate at the University of Western Ontario and a school administrator of a community school in Nanaimo, British Columbia. Sonya Pancucci is a $\mathrm{PhD}$ candidate at Brock University and a grade three teacher in Hamilton, Ontario. 
the social and economic well-being of individuals is subordinated to that of the corporate sector (Jordan \& Strahdee, 2001; Scholte, 2000).

Under the governmental reform agenda of Premier Gordon Campbell, the School Amendment Act of 2002, better known as Bill 34, altered British Columbia's educational landscape. Some observers (Kuehn, 2002; Nelles, 2001) characterize the implementation of Bill 34 as an unprecedented wave of top-down, rapidly implemented educational reform pursuing these explicit goals:

1. increase the fiscal and academic accountability of public education;

2. eliminate the provincial deficit;

3. make the transition toward a market ideology in many aspects of the public education system;

4. mandate the establishment of school planning councils; and

5. expand parental and student choices to attend any schools and programs anywhere throughout British Columbia.

In order to analyse the ideological assumptions of Part 6.1 of Bill 34 and their potential long-term impacts on public education in $\mathrm{BC}$, this paper is divided into three sections. The first section provides an overview of the context that led to the emergence of Bill 34 and reviews the key policy issues and ideas that prompted a policy development debate and policy response by the BC Liberals. The second part addresses the content of Bill 34 in terms of its key components, general purposes, rights and obligations, and assumptions. The third section discusses more specifically the nature, underlying assumptions and potential long-term impacts of Part 6.1 of Bill 34 on public education. This critical analysis employs policy documents (acts, guidelines, directives), policy review documents (white papers, debates, technical reviews), and relevant research literature drawn from the work of researchers who critique the reconfiguration of public education as a commodity within the context of globalization (Ashton \& Green, 1996; Jordan \& Strahdee, 2001; Robertson, 2000; Scholte, 2000).

\section{Context of Bill 34}

The context in which Bill 34 emerged is characterized by global economic developments and demands that are shaping provincial educational policies into a neo-liberal framework that emphasizes shrinking the state sector while promoting market approaches to school choice and program delivery, rational management of school organizations, performance assessment and accountability, and deregulation in order to encourage new "providers" of educational services (Scholte, 2000). These tendencies are embedded in two 
Table 1 - Key Features of the B.C. 2001 Liberal Election Platform on Education Entitled: "A New Era for British Columbia: A Vision for Hope and Prosperity for the Next Decade and Beyond"

\begin{tabular}{|l|l|}
\hline \multicolumn{1}{|c|}{ Policy Issues } & \multicolumn{1}{c|}{ Proposed Policy Options } \\
\hline Mandate of public education & $\begin{array}{l}\text { To put more computers in schools and increase } \\
\text { resources to improve computer literacy for students } \\
\text { To work with employers and post-secondary } \\
\text { institutions to increase training and apprenticeship in } \\
\text { education is to ensure that } \\
\text { individuals have the skills and } \\
\text { knowledge to compete with the } \\
\text { world's best and win. }\end{array}$ \\
$\begin{array}{l}\text { To strengthen the network of colleges and } \\
\text { institutions and on-line learning } \\
\text { To expand job training and skills development } \\
\text { opportunities }\end{array}$ \\
\hline $\begin{array}{l}\text { Access, choice and flexibility } \\
\text { the flexibility and the resources } \\
\text { to meet the students' needs. }\end{array}$ & $\begin{array}{l}\square \text { give school boards more autonomy and control } \\
\text { over the delivery of educational services } \\
\text { To give school boards multi-year funding } \\
\text { envelopes in order to facilitate long-term educational } \\
\text { planning and budgeting } \\
\text { To entitle parents to volunteer their services } \\
\text { provided it does not result in the displacement of } \\
\text { existing staff service } \\
\text { To create new opportunities and better access to } \\
\text { advanced education through skills training, research, } \\
\text { and development }\end{array}$ \\
\hline $\begin{array}{l}\text { Quality and accountability } \\
\text { public education should } \\
\text { autonomy and financial and } \\
\text { academic accountability. }\end{array}$ & $\begin{array}{l}\text { To establish specific goals and outcomes to } \\
\text { measure the success of educators in public } \\
\text { schooling } \\
\text { To devote more of each dollar to improving the } \\
\text { quality of education and less towards bureaucracy }\end{array}$ \\
\hline
\end{tabular}

main policy documents that form the framework used by the BC Liberals in considering educational matters:

1. The 2001 BC Liberal election document on education entitled: "A New Era for British Columbia: A Vision for Hope and Prosperity for the Next Decade and Beyond"

2. "The Select Standing Committee Report on Education" published on March 28, 2002

Table 1 summarizes the key education policy issues raised by the $\mathrm{BC}$ Liberal platform during the provincial election in 2001: far more variation and choice in the delivery of educational services and programs, greater local community input into how schools are run, transformation of the accountability and professionalism of teachers, and promotion of market approaches to school choice. 
These broad ideas were subsequently turned into a more detailed scheme in the form of a report presented as the result of consultation with different stakeholders (The Select Standing Committee Report on Education, 2002). The mandate of the Standing Committee was to report on measures to improve access, choice, flexibility and quality in public education, and to strengthen the network of colleges, institutes and on-line learning throughout the province. Table 2 outlines the key policy issues and options proposed in this report.

Table 2 - Features of the Select Standing Committee on Education Report 2002

\begin{tabular}{|c|c|}
\hline $\begin{array}{c}\text { Key policy Issues Presented in the } \\
\text { Report }\end{array}$ & Proposed Policy Options \\
\hline $\begin{array}{l}\text { Meaning of public education } \\
\text { Public education is the key to a healthy } \\
\text { and a prosperous economy. Its value is } \\
\text { framed by the need for a highly educated } \\
\text { workforce in order to stay competitive in } \\
\text { the knowledge-based global economy. The } \\
\text { report reflects the societal belief that an } \\
\text { educated population has social and } \\
\text { economic value for the individual and for } \\
\text { society }\end{array}$ & $\begin{array}{l}\text { To link work opportunities and schooling } \\
\text { To improve access to further training and } \\
\text { education for workers and students by } \\
\text { increasing the degree of choice and flexibility } \\
\text { within the current system } \\
\text { To offer alternative non-academic post- } \\
\text { secondary courses and programs } \\
\square \text { To develop specialty or magnet schools that } \\
\text { offer skills courses and programs }\end{array}$ \\
\hline $\begin{array}{l}\text { Current initiatives } \\
\text { Attention should be given to social equity } \\
\text { programs to enable children to take } \\
\text { advantage of the educational opportunities } \\
\text { available to them. }\end{array}$ & $\begin{array}{l}\text { To make these non-education programs an } \\
\text { integral part of the public education system }\end{array}$ \\
\hline $\begin{array}{l}\text { Local involvement } \\
\text { The report underlines the value and } \\
\text { relevance of local initiatives and choices } \\
\text { and the advantage of making educational } \\
\text { decisions close to and in consultation with } \\
\text { those who are affected by the decisions. }\end{array}$ & $\begin{array}{l}\text { To allow institutions to make decisions } \\
\text { reflecting local priorities and needs } \\
\text { To provide opportunities for parental input } \\
\text { into decisions affecting their children }\end{array}$ \\
\hline $\begin{array}{l}\text { Access, choice and flexibility } \\
\text { Students should have access to greater } \\
\text { choice and variety in schooling in terms of } \\
\text { relevant education and training } \\
\text { opportunities. }\end{array}$ & $\begin{array}{l}\text { To increase alternative secondary school } \\
\text { programs leading to non-university degree } \\
\text { programs } \\
\square \text { To increase support for independent private } \\
\text { institutions } \\
\square \text { To develop more alternative public schools } \\
\text { including funded charter schools }\end{array}$ \\
\hline $\begin{array}{l}\text { Quality and accountability } \\
\text { The scope and kind of current } \\
\text { measurements of achievement do not } \\
\text { provide an accurate measurement of the } \\
\text { quality of the public education system. }\end{array}$ & $\begin{array}{l}\text { To set more specific goals and standards } \\
\text { to provide clear direction to the public system } \\
\text { To implement accountability measures that } \\
\text { reward achievement and provide for } \\
\text { intervention where effectiveness is not evident }\end{array}$ \\
\hline
\end{tabular}


This report promotes a public education system that is fragmented and focused on localized educational projects that promote choice and difference over uniformity. It is also conceptualized within and connected to larger global trends of less redistribution and increased market-based competition between schools and other service providers. It promotes the politics of difference as the justification for an emphasis on devolution and school choice based on free-market principles. This report replicates the major orientations outlined in the $\mathrm{BC}$ Liberal election platform on education and was used by the government to frame the political debate that led to the enactment of Bill 34 in May 2002.

\section{Content of Bill 34}

Bill 34 promotes four central ideas:

1. Recognition of parental involvement;

2. More choices for students in terms of schools and educational programs;

3. Greater financial flexibility and accountability; and

4. Use of alternate sources of funding by allowing school boards to set up separate entities to engage in entrepreneurial activities.

Table 3 synthesizes the main elements of Bill 34 in terms of purposes, rights and obligations, and underlying assumptions.

The main characteristic of Bill 34 is the promotion of various types of school choice, including alternative schools, magnet schools, and voluntary transfer and open enrolment plans. The idea of choice is the precursor to the other dimensions of Bill 34 as they embrace:

1. a sharp distinction between academic and vocational routes, thus reversing the trend in the Western world against streaming and tracking, developed in the name of educational equity (Ashton \& Green, 1996);

2. a shift of public education toward competence-based skills at the expense of the more fundamental forms of critical competence for autonomous learning and active democratic citizenship;

3. accountability to the "client" as there is ambiguity with respect to who is the real client-the parents, the students or the potential employers-and who should define the nature of the educational service; 
4. a form of competition among schools that allows those with the most valued cultural capital to commodify it in the educational marketplace, and leaving those whose cultural capital is less valued with far less market power (Gewirtz, Ball, \& Bowe, 1995);

5. an atomized decision-making process as responsibility is shifted to a school-based entity that reduces the scope for collective action to improve education for all (Whitty, Power \& Halpin, 1998).

Table 3 - Overview of Bill 34, School Amendment Act, 2002

\begin{tabular}{|c|c|c|}
\hline Purposes & Rights and Obligations & Underlying Assumptions \\
\hline $\begin{array}{l}\text { Enhancing the } \\
\text { opportunity for } \\
\text { parental } \\
\text { involvement } \\
\text { Part 2, Division } \\
2 \text {, sections } 8.1 \\
\text { to } 8.5\end{array}$ & $\begin{array}{l}\text { Bill } 34 \text { requires the } \\
\text { establishment of a school } \\
\text { council in every school in } \\
\text { British Columbia. } \\
\text { The school planning council } \\
\text { is responsible for drawing up } \\
\text { an annual plan that identifies } \\
\text { the school's strengths and } \\
\text { weaknesses, sets goals for } \\
\text { improvements and monitors } \\
\text { its progress. } \\
\text { The school planning council } \\
\text { can make detailed decisions } \\
\text { about how to allocate } \\
\text { resources within the school. }\end{array}$ & $\begin{array}{l}\text { "The most important } \\
\text { determinant of student } \\
\text { success is parental } \\
\text { involvement" (Hansard, 6(14), } \\
\text { 3005). } \\
\text { Schools need "to be } \\
\text { reconnected to their } \\
\text { community in order to } \\
\text { encourage local responsibility } \\
\text { and accountability" (Hansard, } \\
6(14), 3005) \text {. }\end{array}$ \\
\hline $\begin{array}{l}\text { Enhancing the } \\
\text { freedom and } \\
\text { financial } \\
\text { flexibility of } \\
\text { school boards } \\
\text { to make } \\
\text { decisions } \\
\text { according to } \\
\text { their local } \\
\text { needs. } \\
\text { Part } 6 \text {, } \\
\text { Divisions } 1 \text { and } \\
2 \text { - Part } 6.1 \text {, } \\
\text { Divisions } 1 \text { to } 9\end{array}$ & $\begin{array}{l}\text { School boards may share } \\
\text { administrative services with } \\
\text { other school boards, } \\
\text { municipalities, or corporate } \\
\text { entities. } \\
\text { School boards may dispose } \\
\text { of surplus capital assets and } \\
\text { share in the financial gain } \\
\text { proportionate to their share } \\
\text { of the purchase. } \\
\text { School boards may create } \\
\text { separate entities to engage } \\
\text { in entrepreneurial activities } \\
\text { to market their intellectual } \\
\text { capital. }\end{array}$ & $\begin{array}{l}\text { The creation of competitive } \\
\text { arrangements between } \\
\text { school boards' personnel and } \\
\text { outside "service providers" } \\
\text { bring about a more cost } \\
\text { efficient delivery of services" } \\
\text { (Hansard, 7(12), 3398). } \\
\text { The school boards' ability to } \\
\text { generate revenues through } \\
\text { other sources allow them to } \\
\text { better meet local educational } \\
\text { needs. "There are } \\
\text { opportunities to bring some } \\
\text { money home for BC kids" } \\
\text { (Hansard, 7(7), 3250). }\end{array}$ \\
\hline
\end{tabular}




\begin{tabular}{|c|c|c|}
\hline Purposes & Rights and Obligations & Underlying Assumptions \\
\hline $\begin{array}{l}\text { Holding school } \\
\text { boards } \\
\text { accountable for } \\
\text { financial and } \\
\text { academic } \\
\text { matters. } \\
\text { Part 2, Division } \\
\text { 2, sections79.2 } \\
\text { and } 80\end{array}$ & $\begin{array}{l}\text { School boards must } \\
\text { complete accountability } \\
\text { contracts. } \\
\text { A special advisor may be } \\
\text { appointed to review the } \\
\text { progress of boards where } \\
\text { they are not meeting the } \\
\text { goals of student } \\
\text { achievement. }\end{array}$ & $\begin{array}{l}\text { The school system tends "to } \\
\text { focus on the means of } \\
\text { education without sufficient } \\
\text { attention to the outcomes. } \\
\text { The system is driven by the } \\
\text { interests of the system or the } \\
\text { service provider rather than } \\
\text { the interests of the leamer } \\
\text { and the public" (Hansard, } \\
6(14), 3007 \text { - 3009). }\end{array}$ \\
\hline $\begin{array}{l}\text { Providing } \\
\text { choices in } \\
\text { terms of } \\
\text { schools and } \\
\text { educational } \\
\text { programs. } \\
\text { Part } 6 \text {, Division } \\
2 \text {, sections } \\
74.1 \text { to } 75.1\end{array}$ & $\begin{array}{l}\text { Students will be able to } \\
\text { attend schools in any } \\
\text { catchment area in BC } \\
\text { (subject to space availability). } \\
\text { Schools must be more } \\
\text { responsive to the needs of } \\
\text { their community of learners. }\end{array}$ & $\begin{array}{l}\text { The creation of competitive } \\
\text { arrangements between } \\
\text { schools and school boards } \\
\text { provides them with an } \\
\text { incentive to improve and be } \\
\text { more responsive to their } \\
\text { community of consumers } \\
\text { (Hansard, } 6(14), 3025) \text {. }\end{array}$ \\
\hline
\end{tabular}

The main assumption is that the introduction of market principles and consumer choice into the organisation of schooling will ensure a more efficient delivery of education and enhance its quality. However, some scholars argue that such a policy exacerbates the problems of inequality of educational opportunity, as individuals with cultural and financial capital are able to maximise schooling to their own educational advantage, to the disadvantage of others who cannot (Jonathan, 1989; Ball, 1994; Adler, 1997). The consequence is intensified social segregation as public education becomes a commodified good, one subject to divisibility and excludability (Ball, 1994).

\section{Part 6.1 of Bill 34}

In the context of Bill 34 and within its main feature of educational choice, commodification is the crucial structural effect that illustrates how the neoliberal form of globalization can influence policy making in public education (Scholte, 2000). Part 6.1 of Bill 34 allows public school districts to create legal entities to engage in competitive entrepreneurial activities, such as providing consulting services and educational or administrative expertise and promoting international education through the recruitment of foreign students or the establishment of offshore BC schools designed as profit centres. This part of Bill 34 introduces the institutional dynamics of entrepreneurialism and 
competitiveness in delivering and funding public education. Similar legislation implemented in Australia, New Zealand, the United Kingdom, and the United States has been designed to enable school districts to make up shortfalls in government funding through recruiting foreign fee-paying students, creating offshore private schools, and trading educational expertise and services (Robertson, 2000).

Part 6 of Bill 34 reconceptualizes school districts and their teachers as competitive units within the national and global economies as it is assumed that:

1. school districts should become more "entrepreneurial," that is, be more responsive to and governed by the preferences of the community of consumers they seek to serve in the marketplace;

2. the creation of more competitive arrangements between school districts will deliver better educational services in terms of efficiency, quality, product differentiation, product management, and the capacity to react quickly to consumer needs; and,

3. trading educational services and programs will augment financial resources for public education.

This part of Bill 34 delivers up some aspects of school district activities to the marketplace, whose mechanisms will reshape them toward the requirement of profit-making. The policy option embedded in Part 6.1 looks for school districts to engage directly in revenue-making activities by viewing knowledge as an exportable commodity. The main outcome of such a policy option for school districts is that they could become more instrumentally focused on externally controlled definitions of educational process and product regulated by a market mode. Furthermore, this part of Bill 34 may lead to competition between school districts; it will allow those with the most valued cultural capital in the eyes of choice-conscious parents to market it as an individual benefit to their children rather than as a service to the public, while districts with less valued cultural capital hold far less market power. What takes place within a school district in terms of day-to-day learning and instruction may become less important than the marketing signs and symbols that represent the type of students and parents who choose a given school district and the culture and value system they hold dear. It could lead school districts to act more and more as entrepreneurial units rather than as institutions with social interests and responsibilities (Robertson, 2000). The school districts with the 
most powerful symbols win in the educational market (Gewirtz, Ball, \& Bowe, 1995).

\section{Conclusion}

Academic choices and open enrolment, efficiency through accountability, entrepreneurialism, and competition underpinned Bill 34. Unfortunately, it has set the stage for public education in British Columbia to view knowledge as a commodity and to link, at least partially, the levels of services and of funding of public education to the entrepreneurial success of individual school districts rather than to an equitable distribution of public resources. The logic of the free market is strongly embedded in Bill 34 and market mechanisms are introduced to capitalize upon choice and efficiency the dominant values in British Columbia's current political culture.

It is too early to fully understand how these new institutional dynamics will shape public education in British Columbia in the long term. Bill 34 is barely two years old and further research is needed to gauge its impact on governance and funding, teachers' work and identities, conceptualization of teaching and learning, teachers' identities, organizational structures of school districts, the mandate of public education, and the roles of school. However, we can draw from the experience of countries that have adopted similar policy options and legislation. Studies done in Australia, New Zealand, the United Kingdom, and the United States clearly show that educational policy options based on entrepreneurialism, choice, and competition promote a form of competition between school districts that allow only those with the most valued cultural capital to commodify it in the marketplace, leaving others with limited access to diminishing public and private resources (Delhi, 1996; Kenway \& Epstein, 1996; Robertson, 2000; Wells, Lopez, Scott, \& Holmes, 1999). A design that turns school districts over to market forces and gives parents more choice does little to alleviate social divisions and promote equity, heterogeneity, pluralism, and local needs (Wells, Lopez, Scott, \& Holmes, 1999).

Regrettably, public education in British Columbia is rapidly becoming a commodity, something to be produced, packaged, sold, traded, franchised, and consumed. In this new dynamic, public school districts are forced to compete against each other. The viability of those that do not compete successfully could be threatened. School districts will need to market and sell their expertise and programs effectively in order to keep enrolment and revenue at a healthy level. School districts are being transformed into corporate entities geared toward the ideal of making a profit in a consumer-driven public system based 
on factors such as product differentiation, product management, economic instrumentalism, and the capacity to react quickly to choice-conscious parents.

\begin{abstract}
Authors' Note
The authors would like to thank Dr. Greg Dickinson (UWO) for his helpful comments on an earlier draft of this paper.
\end{abstract}

\title{
References
}

Adler, M. (1997). Looking backward to the future: Parental choice and education, British Educational Research Journal, 23, 297-313.

Ashton, D. \& Green, F. (1996). Education, training and the global economy. Chetlham, UK: Edward Elgar.

Ball, S.J. (1994). Education reform. Buckingham, UK: Open University Press.

BC Liberals. (2001). A new era for British Columbia: A vision for hope and prosperity or the next decade and beyond. Retrieved January $7^{\text {th }}, 2003$, from http://www.bcliberals.com.

British Columbia, Select Standing Committee on Education (2002). A future for learners: A vision for renewal of education in British Columbia.

Victoria, BC: Ministry of Education, Governance and Legislative Unit.

British Columbia. (2002). Bill 34, School Amendment Act - 2002. Victoria, BC:

Ministry of Education, Governance and Legislation Unit.

British Columbia Hansard Services. (2002). Official report of debates of the Legislative Assembly, $3^{\text {rd }}$ session, $37^{\text {th }}$ Parliament, Hansard, 6(14), 2997-3043.

British Columbia Hansard Services. (2002). Official report of debates of the Legislative Assembly, $3^{\text {rd }}$ session, $37^{\text {th }}$ Parliament, Hansard, 6(16), 3086-3089.

British Columbia Hansard Services. (2002). Official report of debates of the Legislative Assembly, $3^{\text {rd }}$ session, $37^{\text {th }}$ Parliament, Hansard, 7(1), 3099-3121.

British Columbia Hansard Services. (2002). Official report of debates of the Legislative Assembly, $3^{\text {rd }}$ session, $37^{\text {th }}$ Parliament, Hansard, 7(7), 3250-3261.

British Columbia Hansard Services. (2002). Official report of debates of the Legislative Assembly, $3^{\text {rd }}$ session, $37^{\text {th }}$ Parliament, Hansard, 7(12), 3377-3424. 
Delhi, K. (1996). Between market and state? Engendering education change in the 1990s. Discourse: Studies in the Cultural Politics of Education, 17, 363-376.

Gerwirtz, S. Ball, S, \& Bowe, R. (1995). Markets, choice and equity. Milton Keynes: Open University Press.

Jonathan, R. (1989). Choice and control in education: Parental rights, individual liberties and social justice, British Journal of Educational Studies, 37, 321-338.

Jordan, S. \& Strahdee, R. (2001). The training gospel and the commodification of skills: Some critical reflections on the politics of skills training in Aoteara/New Zealand. Journal of Vocational Education and Training, 53, 391-403.

Kenway, J. \& Epstein, D. (1996). Introduction: The marketization of school education: Feminist studies and perspective. Discourse: Studies in the Cultural Politics of Education, 17, 301-314.

Kuehn, L. (2002). B.C. Liberal push boards to market education. Teacher: NewsMagazine of the BC Teachers' Federation, 15(2), 1-3.

Nelles, W. (2001) The world of education market comes to Canada: Competition in a trillion dollars global industry. Retrieved January $7^{\text {th }}$, 2002 from http://www.bctf.ca/Education/NoToWEM/ NellesArticle.html.

Robertson, S.L. (2000). A class act: Changing teachers' work, globalization and the state. New York, NY: Falmer Press.

Scholte, J.A. (2000). Globalization: A critical introduction. London, UK: Palgrave.

The Select Standing Committee on Education Report. A future for learners: A vision for renewal of education in British Columbia. Retrieved December $12^{\text {th }}, 2002$, from http:// www.legis.gov.bc.ca.

Wells, A.S., Lopez, A., Scott, J. \& Holmes, J.J. (1999). Charter schools as postmodern paradox: Rethinking social stratification in an age of deregulated school choice. Harvard Educational Review, 69, 172-203.

Whitty, G., Power, S., \& Halpin, D. (1998). Devolution and choice in education: The school, the state, and the market. Birmingham, UK: Open University Press. 